\title{
Construction of English-Assisted Teaching Mode Based on Multimedia Technique in Network Environment
}

\author{
Qiong Yue \\ Department of Humanity and Art, Heyuan Polytechnic, Heyuan 517000, China \\ Correspondence should be addressed to Qiong Yue; smile131400@163.com
}

Received 13 December 2021; Revised 1 January 2022; Accepted 3 January 2022; Published 2 February 2022

Academic Editor: Xin Ning

Copyright (@ 2022 Qiong Yue. This is an open access article distributed under the Creative Commons Attribution License, which permits unrestricted use, distribution, and reproduction in any medium, provided the original work is properly cited.

\begin{abstract}
Modern educational technology, embodied by multimedia network technology, is now widely used in education and teaching, and it offers distinct benefits in terms of improving classroom teaching effectiveness. Through videos, sounds, images, and animations, multimedia English teaching can show students all kinds of information more intuitively, vividly, and quickly. This paper attempts to apply multimedia-assisted teaching to the English classroom, combining the characteristics of the English subject and the requirements of curriculum standards, based on related theories of psychology and information technology. The learning effect can be established with the CET effective classroom environment construction and the three dimensions of the teaching process reflected by the evaluation scale and the path model with a good fitting degree. Teachers' correct guidance will play a positive role in learners' correct use of multimedia English learning resources, according to teaching practice. A simulated language environment can be created using multimedia technology, allowing students' sensory organs to be activated more effectively, their attention to be drawn in, and their interest in English learning to improve.
\end{abstract}

\section{Introduction}

With the rapid development of information technology, network multimedia technique, as an auxiliary means of teaching, plays an important role in college English teaching (CET) activities. The continuous development and application of multimedia technique in Chinese society has brought great convenience to people's daily life [1]. At the same time, the wide promotion and application of multimedia technique in the education industry have also set off the reform and change of teaching methods [2]. Language is the product of social development, and language has remarkable characteristics of the times. English resources on the Internet, such as English news, English songs, English movies, and TV programs, can well reflect the language with characteristics of the times [3]. A multimedia network learning environment can provide a space and support for cooperative learning among students. Learners' cooperative spirit, mutual assistance consciousness, and cooperative skills can all be cultivated through cooperative learning in a multimedia network environment [4]. According to constructivism theory, learning is a process of combining original background knowledge and using new information to constantly construct new knowledge, rather than passively receiving information. As a result of the different background knowledge of individuals, the acceptance degree of learning individuals to information varies in the process of knowledge construction [5]. With the help of multimedia techniques and network technology, teachers can enrich teaching forms and contents and mobilize students' initiative in the classroom. Under the new circumstances, the teaching method of prioritizing teaching over students' passive learning is no longer appropriate for college teaching [6].

Multimedia is a new product of science and technology. Connecting multimedia with our life and learning can not only enhance our interest but also improve our academic performance. Network multimedia course teaching creates a more three-dimensional, advanced, and optimized language teaching environment for college English classroom [7]. It can help college English teachers build a new teaching model. The combination of multimedia technique and 
college English curriculum can not only effectively promote the effective development and improvement of college students' listening and speaking ability but also simulate and show the actual pragmatic environment and strengthen college students' comprehensive English application ability [8]. The teaching of college English course focuses on cultivating college students' English communicative competence in real life, involving many teaching contents such as oral English and listening [9]. The application of information technology to English subjects can better realize diversified teaching and learning methods, change the traditional teaching classroom form, attract students' attention, and better develop students' comprehensive ability to collect, screen, analyze, and process information [10]. Based on the relevant theories of psychology and information technology, combined with the characteristics of English and the requirements of curriculum standards, this paper attempts to apply multimedia assisted teaching to English classroom and puts forward feasible improvement measures for the shortcomings of English teaching. This paper first discusses the advantages of network multimedia technology in college English teaching and then constructs a multimedia Englishassisted teaching mode based on multimedia teaching methods and verifies the effectiveness of multimedia teaching methods in the part of result analysis and discussion.

In the past, English teaching often used the teaching method of teachers' teaching and students' passive learning. The teaching form is too single, and it is often difficult to obtain significant results [11]. Language is the product of social development and has remarkable characteristics of the times. English resources on the Internet, such as English news, English songs, English movies, and TV programs, can well reflect the language rich in the characteristics of the times [12]. In order to achieve the goal of educational reform as soon as possible, it is very necessary to apply computeraided teaching means to English teaching [13]. In English teaching, it is very important to provide a good oral environment, and the use of multimedia to assist teaching has obvious advantages in this regard [14]. This paper discusses the importance of multimedia teaching methods in CET, the issues that should be addressed in CET, and the research and analysis of the teaching effect of multimedia techniques in CET. The findings show that using multimedia techniques improves not only the teaching content, but also the teaching methods, the interest, and diversity of English classroom teaching, and has some practical value in enhancing the effect of College English classroom teaching. Learners can choose online English learning resources based on their own interests in the multimedia network environment. The cooperative relationship between English teachers and learners has been further consolidated and strengthened in English teaching activities conducted in a multimedia network environment, ensuring the smooth progress of CET reform.

\section{Related Works}

Students' curiosity and interest in learning can be piqued using multimedia to import preset scenes. The new curriculum emphasizes students' dominant position, and one of the important criteria for determining a class's success is how to lead students into a preset situation during the leadin before class [15]. Multimedia techniques are widely used in English teaching under the new curriculum reform, which fundamentally breaks through the limitations of time and region. Students can actively participate in learning based on their own learning circumstances, complete teacher-assigned tasks on the Internet, broaden their interests, and strengthen their weak links [16]. According to constructivism theory, learning is not a passive process of receiving information but rather a process of combining background knowledge and constantly building new knowledge using new information [17]. Ordinary teachers believe that information technology can optimize the teaching process and improve teaching efficiency, but only as a tool; researchers, on the other hand, believe that the integration of the two is a process of reforming teachers' teaching quality and changing teachers' teaching methods as well as students' learning methods [18]. Literature [19] points out that the change in teaching mode and technology also makes CET no longer limited by time and space and more and more independent and media-based learning. Literature [20] shows that English learning needs to be in a language environment with strong interaction and communication, rather than a language environment with too much emphasis on learning grammar rules and language structure. Literature [21] shows that the application of multimedia technique in teaching can give full play to the teaching effects of sound, image, video, and bionic special effects, thus making CET methods show a diversified development trend, enriching the content of classroom teaching, and effectively promoting students' learning enthusiasm and creativity. Based on the previous research results, the main purpose of this study is to summarize the feasible multimedia-assisted English teaching process and to provide reference for front-line English teachers in English teaching. This study pays more attention to highlighting students' dominant position in multimedia-assisted English teaching and promotes students' comprehensive development.

\section{Advantages of Network Multimedia Technique in CET}

3.1. Providing an Ideal Teaching Environment. Traditional teaching methods place an excessive emphasis on teachers' main role in teaching while ignoring the importance of students' active participation, resulting in boring lessons that have negative consequences such as students' interest waning and fatigue with learning. Through the combination of situation and language, English teaching using network multimedia technique abandons the problems that exist in traditional English teaching, creates a more intuitive language environment for students, and constructs a brandnew cognitive model and teaching environment. Teachers should take full advantage of their leadership role in the multimedia network environment in English classes, which is primarily reflected in the selection of existing courseware 
and the creation of new courseware, while also grasping the frequency of using multimedia and network in class. We can make more vivid teaching courseware, create richer and more vivid teaching situations and contexts, and make English teaching content more vivid and appealing with the help of multimedia. Simultaneously, the types of multimedia teaching are becoming more diverse, allowing students' vision, hearing, and other senses to be trained, as well as their ability to accept new information.

3.2. Enhancing Students' Interest. Students' language learning is not only a simple transfer of knowledge but it is also the use of sensory organs to transfer the objective world described in one language to the objective world described in another language. In this process, perceptual knowledge needs to be transformed into rational knowledge and then used flexibly. In the past English teaching, teachers often played a major role and played a key role in the success of teaching. Students were participants, and students could only passively learn and accept knowledge. After using the multimedia teaching system, teachers only need to do a good job in designing courses, asking questions, and solving problems [22]. English teaching can also make students become the subject of learning both inside and outside the classroom through the form of students' autonomous learning and terminal operation, arouse their learning initiative and enthusiasm, and make students consciously participate in English learning by changing learning forms, so as to improve English learning efficiency. When students encounter learning problems, they can first find answers with the help of network tools and actively think about solutions to the problems. In this process, it is particularly easy to improve students' ability to think independently and solve problems.

\subsection{Classroom Capacity and Depth Can Be Expanded} Infinitely. Teachers in a multimedia networked classroom cannot ignore classroom interaction, that is, communication between students and teachers, to increase the amount of information available to students. Teachers should make their roles in the classroom clear in order to achieve better results in the multimedia network classroom environment [23]. Teachers should plan all of the activities in the classroom. Instead of copying the courseware content, teachers should carefully select it before each class. The use of multimedia techniques in the classroom has greatly enriched classroom teaching resources, allowing teachers to display background knowledge, current events news, and other information related to textbooks through various materials, ensuring that students have access to more and richer teaching resources and experiencing western culture in the classroom. English teachers should make the best use of online English resources in their English teaching activities in a multimedia network environment so that they can better serve teaching, understand the frequency of using multimedia and the Internet in class, ensure the leading role of English teachers in class, and guide learners to actively learn in and out of class.

\section{Construction of the Multimedia-Assisted English Teaching Model}

In the multimedia network English classroom environment, learners are not passive recipients of information, but collaborators of classmates and teachers. In the multimedia network classroom environment, learners experience the novelty and large amount of information brought by modern teaching methods, and at the same time, they also put forward new requirements for learners themselves. The related multimedia facilities can help solve the problem of children's listening equipment, and there are also corresponding measures and methods in oral exercise. Of course, teachers also play a great guiding role in this process. Teachers should strengthen and supervise their learning process. If there is any problem, they should consult teachers modestly in time. Activities organized by teachers in the classroom require learners to cooperate with each other, and whether learners can cooperate well is largely determined by learners' preparation before class [24]. Therefore, to be a good collaborator and collaborator, learners must make full use of network resources. By linking the English learning websites introduced by teachers and reading the learning materials published by teachers online, the efficiency of learners' autonomous learning after class can be guaranteed. Figure 1 shows the communication process model in education.

Students can use multimedia laboratories and carry out the "second classroom" just like the audio-visual room now in a good teaching environment with multimedia laboratories and advanced and excellent English teaching software. Compared with other teaching methods, multimedia has greatly improved the novelty of teaching, making the classroom more vivid and increasing students' desire to be in it. One of the language learners' strategies is to use online English resources. Because learners are the main body of language learning, cultivating learners' learning strategies is an important link that cannot be overlooked in CET reform. Learners use language learning strategies both consciously and unconsciously while using online English resources. Teachers can turn teaching objectives into corresponding learning themes through the analysis of teaching objectives and use themes to stimulate students' learning enthusiasm and interest, thereby making learning an intrinsic demand and attracting students to actively participate in learning. The relationship between computer, teaching content, teachers, and students is shown in Figure 2.

English learning under the multimedia network environment plays an active role in cultivating learners' language learning strategies. Second, English teaching under the multimedia network environment requires and can promote learners' autonomous learning. English teachers should give full play to learners' cognitive potential and create conditions for learners' active learning. Constructivism emphasizes the creation of real situation and regards it as the necessary premise of "meaning construction." Through teachers' thematic learning website resources, real situations are created, related to 


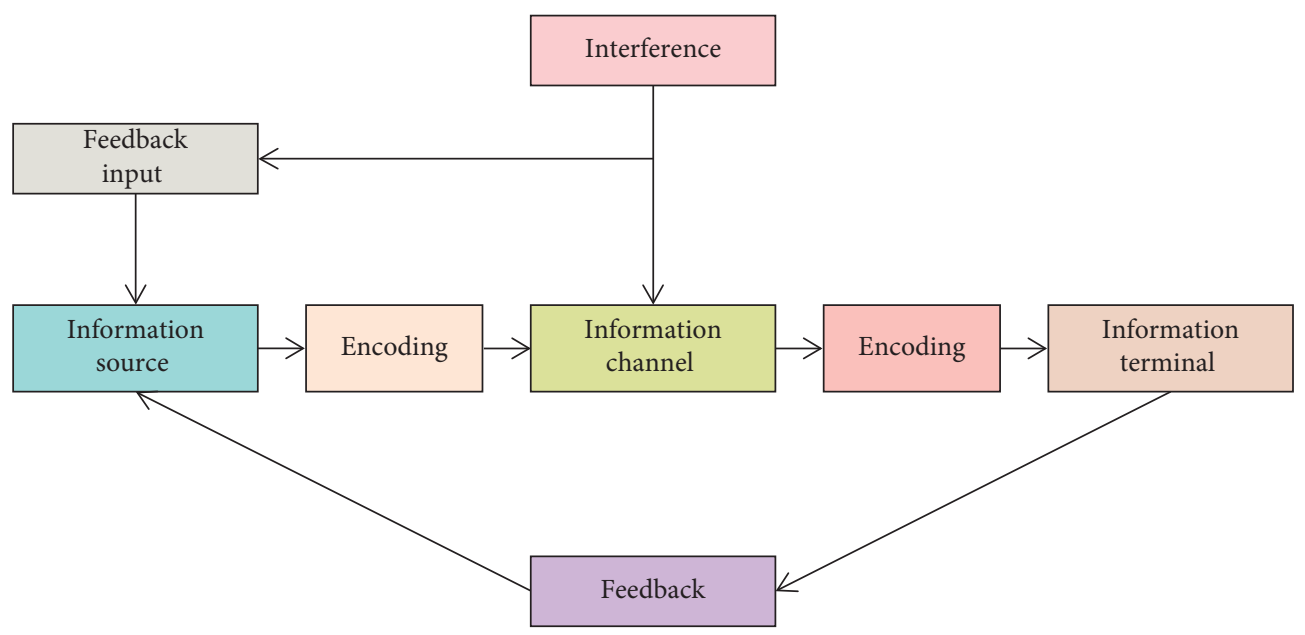

FIGURE 1: Communication process model.

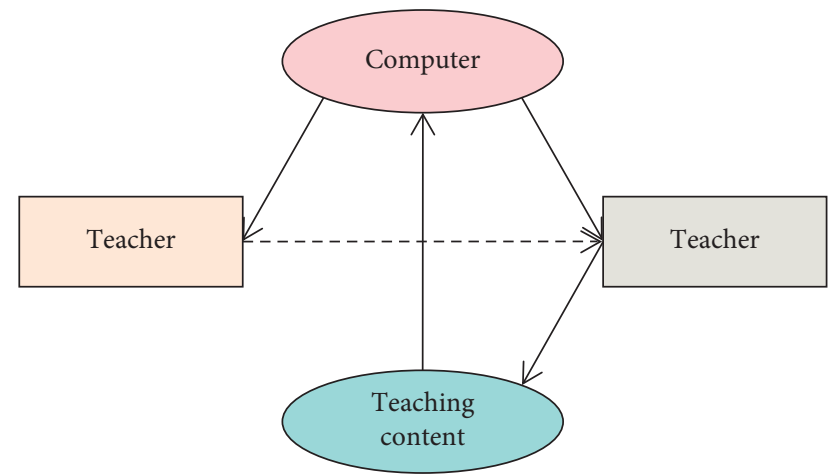

FIgURE 2: The relationship between computers, teaching content, teachers, and students.

current learning topics [25]. Students use vivid and intuitive images to effectively stimulate association and awaken relevant knowledge in long-term memory, so that students can assimilate current new knowledge by using relevant knowledge and experience in their original cognitive structure. Figure 3 is a path analysis model of multimedia English classroom environment construction dimension and learning effect.

They can benefit from online English learning resources as college students with strong cognitive abilities. The cooperative relationship between learners has been strengthened in the multimedia network classroom environment. Multimedia is not only a teaching aid for teachers, but also a tool for students learning and engaging in foreign language activities. Teachers should dig up teaching materials, create learning tasks, and guide students to explore and learn actively, starting with the teaching content and students' realities. Teachers must identify topic-related information resources, collect and manage the information, design and provide corresponding information resources and search methods, and use the network to create a cooperative learning platform that allows students to use the platform's multitype and multimode learning resources for hierarchical, phased, and personalized learning.

\section{Results Analysis and Discussion}

5.1. English Audio-Visual Teaching. In the process of language communication, it is impossible and unnecessary for the speaker to express any details for the sake of economy of language expression. Students should read extensively outside class and accumulate more knowledge of English cultural background, so as to be helpful in listening. In addition to intensive listening training for students in listening class, teachers should also pay attention to arranging corresponding extracurricular extensive listening materials according to different students' language and pragmatic level, encourage students to combine intensive listening and listening in and out of class, and effectively improve students' foreign language listening and discrimination ability. After class, learners should make use of the Internet for autonomous learning. In class, learners actively participate in various classroom activities through the multimedia courseware provided by teachers [26]. Compared with English classroom in traditional teaching environment, learners have changed from passive receivers of knowledge to active extractors of knowledge. Multimedia English learning environment can better mobilize learners' enthusiasm. Teachers can arrange online homework forms, such as asking learners to find out some proverbs related to friendship on the Internet and express their opinions, and send them to teachers in the form of e-mail. In this process, learners learn to learn actively.

Students have done task-based listening learning before class, and the learning results can be performed and displayed in class. Culture is a unique creation of human beings that is different from other animals, including all material and spiritual achievements created by human beings. The parameter of the language model is a multidimensional vector, and the conversion string score can be written as

$$
D_{i}=a+\sum_{j=1}^{n} b_{j} p_{j}+r_{i} Y+u
$$




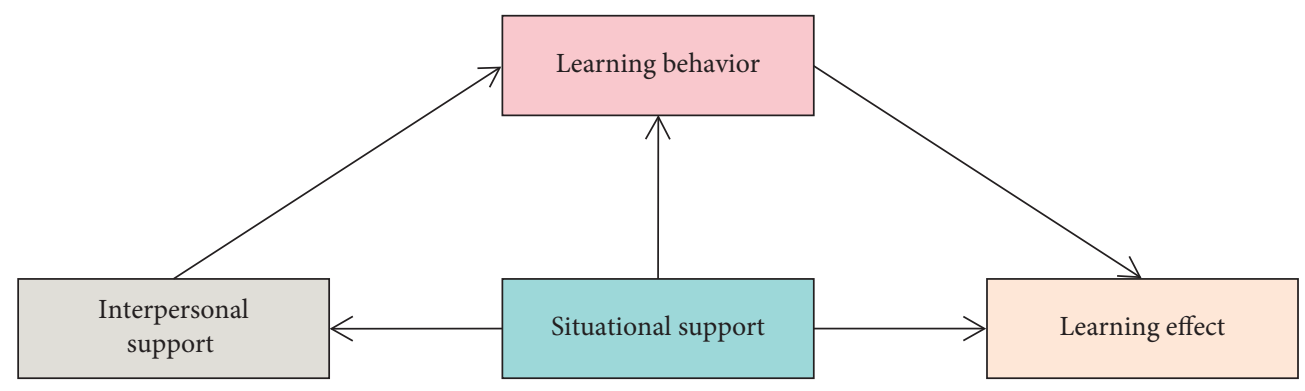

Figure 3: Path analysis model.

This improves the flexibility and effectiveness of teaching. It also improves students' comprehensive abilities in three aspects: seeing, listening, and speaking. Decision can be written as

$$
D_{i}=a+\sum_{j=1}^{n} b_{j} \ln \left(p_{j}\right)+r_{i} \ln (Y)+u .
$$

The traditional listening teaching model leads to students' lack of comprehensive mastery of listening methods and skills, and it is difficult to improve their listening level. Due to the limitations of teaching time and teaching means, teachers cannot design teaching content according to the actual situation of students, cannot get learning feedback for individual students, and cannot teach students in accordance with their aptitude and give classified guidance. See if the teacher can grasp the key and effectively reveal the logical connection between the knowledge before and after. It also depends on whether teachers and students are reasonable, effective, and skilled in developing and utilizing multimedia and network resources to assist teaching and so on. The center of the classroom is students, not teachers. The role of students is not only to cooperate with teachers' teaching steps but also to actively participate in and actively contribute the acquired information and knowledge. Teachers should pay attention to training students to analyze useful genre knowledge and useful expressions from listening and reading materials and let them use these knowledge to complete productive tasks in time, which will accelerate the process of language internalization. After the implementation of English teaching stage supported by multimedia technique is completed, a test should be conducted. The test results are shown in Figure 4.

Listening is a form of positive thinking. It is necessary to make incremental breakthroughs in order to improve students' listening comprehension abilities. Various listening teaching organization forms, as well as teaching methods that combine listening and speaking, are beneficial in reducing students' anxiety. Choose simple and easy-to-understand clips that are close to the reality of life, from simple to deep, step by step, for students with poor listening skills, and help them to overcome their fear of difficulties. Students can follow keywords and phrases while listening and distinguishing and then retell what they heard. Finally, play the material again so that students can grasp the overall structure of the dialogue as well as the speaker's emotional attitude.
When teaching is student-centered, it is all too easy to overlook the importance of teachers' roles and deviate from the expected teaching objectives. Teachers should plan ahead of time for cooperative learning tasks and assign and coordinate students to complete them. To avoid dampening students' enthusiasm, teachers should give specific feedback on their performance. Schools and teachers should collaborate to create a multimedia resource database and an exercise question bank. Students can study independently after class and appreciate the variety and flexibility of multimedia courses. Students can use the online autonomous learning platform to learn listening at any time and from any location, allowing them to learn English at any time and from any location. Individualized and self-directed learning is a requirement in the classroom. Encourage students' critical thinking and assist them in comprehending information. Allow students to become immersed in the language's surface and connotation. Students learn, discuss, negotiate, and cooperate independently in group discussions, class speeches, role-playing, and other activities.

\subsection{Construction of Effective Classroom Environment. In} actual teaching, teachers should give necessary explanations on cultural background knowledge. When people are relaxed and interested, they will have a longer time to concentrate and a better listening effect. On the contrary, if the enthusiasm is weakened, or when you feel nervous and anxious, the auditory nerve is suppressed and you cannot concentrate. Multimedia is a teaching means, not an end, and video materials are given to students to stimulate interest and arouse enthusiasm. If used excessively, it will lead to students' visual fatigue and lack of excitement about language points, which is counterproductive. If you only play the video and practice too little, it will not consolidate. Under the traditional listening teaching mode, English listening teaching is usually done in the language lab twice a week. The construction and evaluation scale of effective classroom environment in college English is tested by a large number of samples to verify whether the scale conforms to the established theoretical model. In order to further deepen the teachers' understanding of the construction of effective classroom environment in college English, promote effective classroom teaching and provide theoretical and practical reference.

In the English classroom under the multimedia network environment, teachers and students should establish a good cooperative relationship. Multimedia network should not 


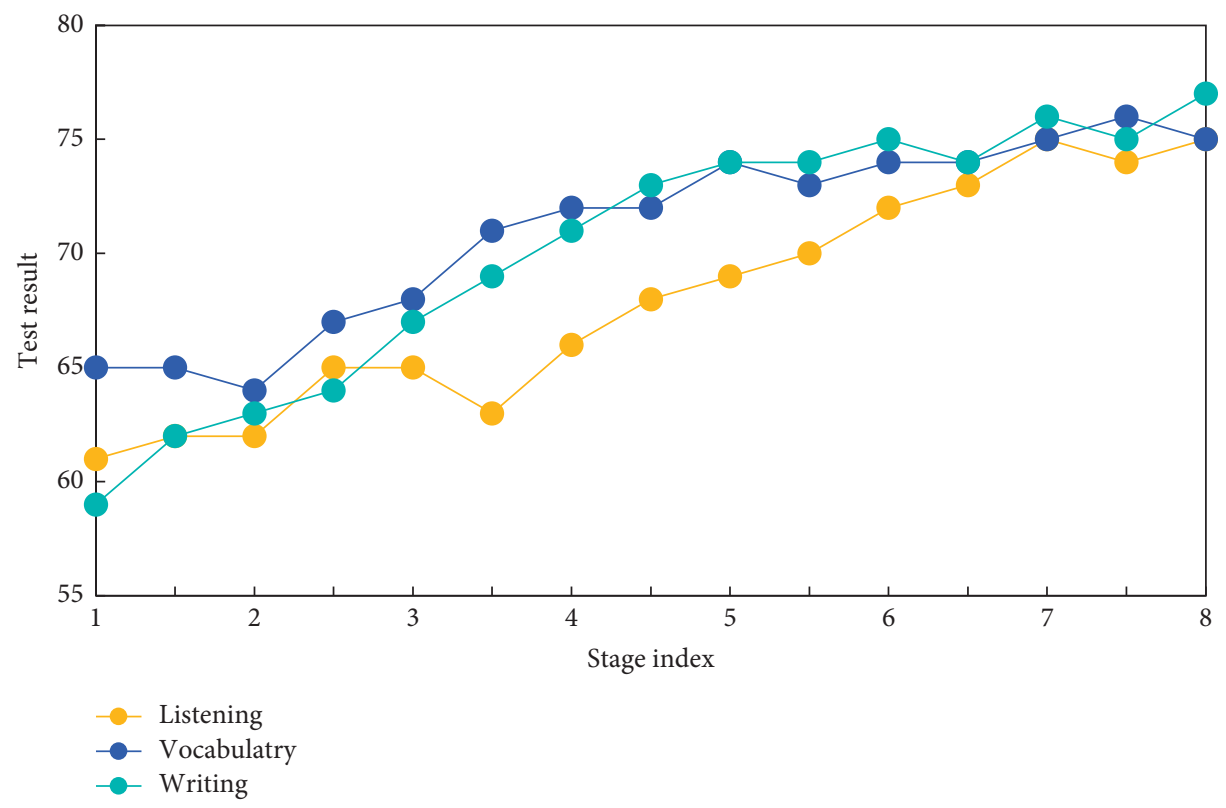

Figure 4: Test results.

only be a tool for teachers to impart knowledge, but also a tool for learners to learn. Teachers and learners can use the network to communicate in time, and teachers can know learners' learning needs in time. Data reconstruction is carried out on the constraint parameters of CET ability evaluation, and the time domain waveform shown in Figure 5 is calculated.

In the multimedia network classroom environment, teachers should make proper use of multimedia, and multimedia should not take the place of teachers. If you rely too much on multimedia, the result will be that students are busy copying the contents of courseware in class. Therefore, teachers should have appropriate control over the amount of information in class. From the teacher's point of view, because learners are busy copying notes, teachers have less time to ask questions in class. Taking the statistical results of English teaching ability evaluation as the research object, data clustering and information fusion are carried out to complete the teaching ability evaluation. Comparison of the two analysis methods is shown in Figure 6.

From the results, it can be seen that the accuracy of teaching ability evaluation with this method is high, and the utilization rate of teaching resources is good. Each class or unit should focus on a theme. All multimedia materials should be closely related to this theme. This can strengthen students' impression and make each practice activity related to facilitate students' review. In the three dimensions of the construction of effective classroom environment in college English, interpersonal support and situational support interact with each other and jointly influence the dimension of learning behavior. It conforms to the basic explanation of the three-dimensional relationship in the theoretical model, and it is also a further refinement of the definition of the three-dimensional relationship. Classroom teaching evaluation system is a series of index systems for evaluating teachers' classroom teaching behaviors based on the definition of excellent teachers. There is

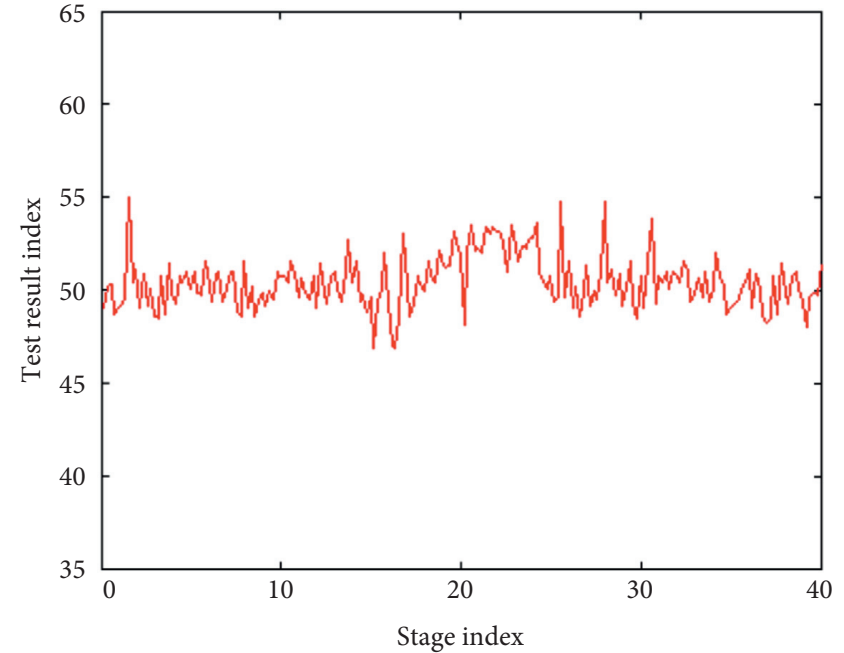

Figure 5: Time-domain waveform of big data time-domain distribution.

a significant correlation between interpersonal support and situational support, and the correlation coefficient is high. This shows that students need to feel the harmonious interpersonal relationship and the promotion of classroom situation to their own learning in the process of classroom learning.

Teachers can evaluate students' learning through the network examination system, monitor the learning process by using the network Q\&A and interactive system, and evaluate all aspects of students' cooperative learning process. Students can also make the evaluation more scientific, rational, and objective through the group's personal evaluation and students' self-evaluation. In the case of daily writing practice in two classes, the average number of effective words in English composition changes with the start time of the experiment as shown in Figure 7. 


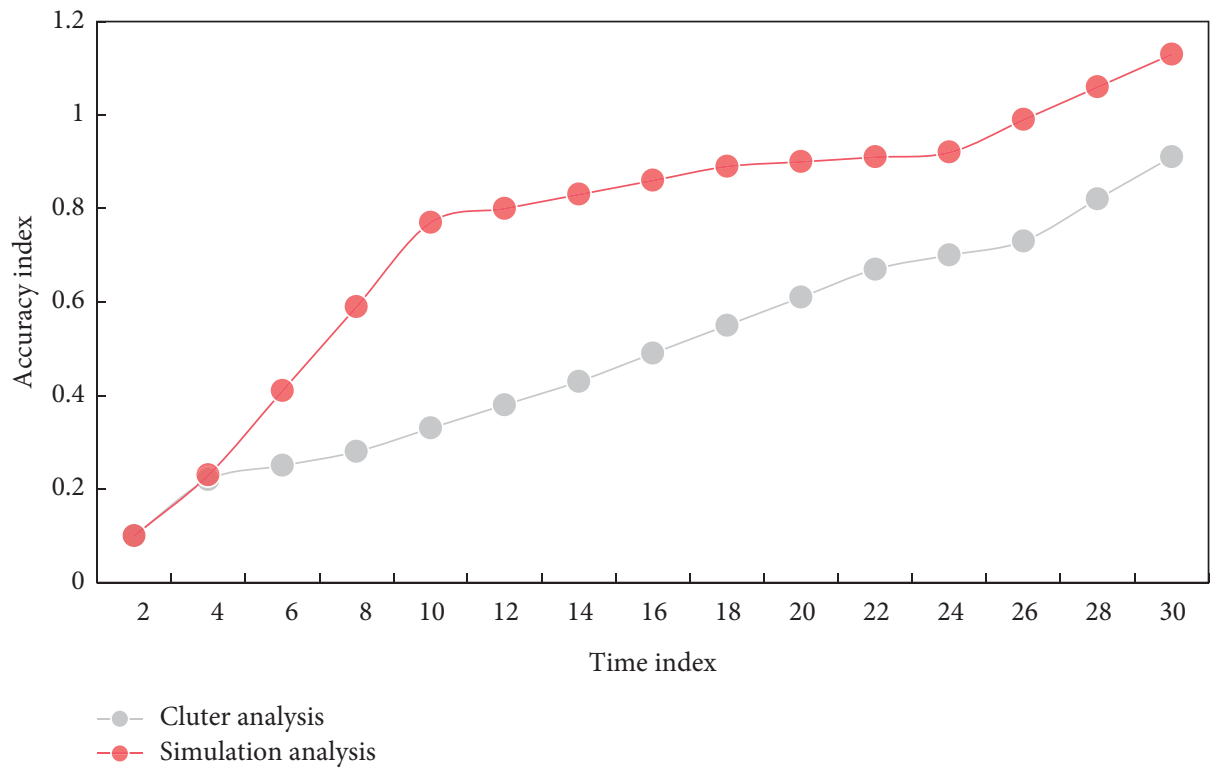

Figure 6: Comparison of accuracy data of two analysis methods.

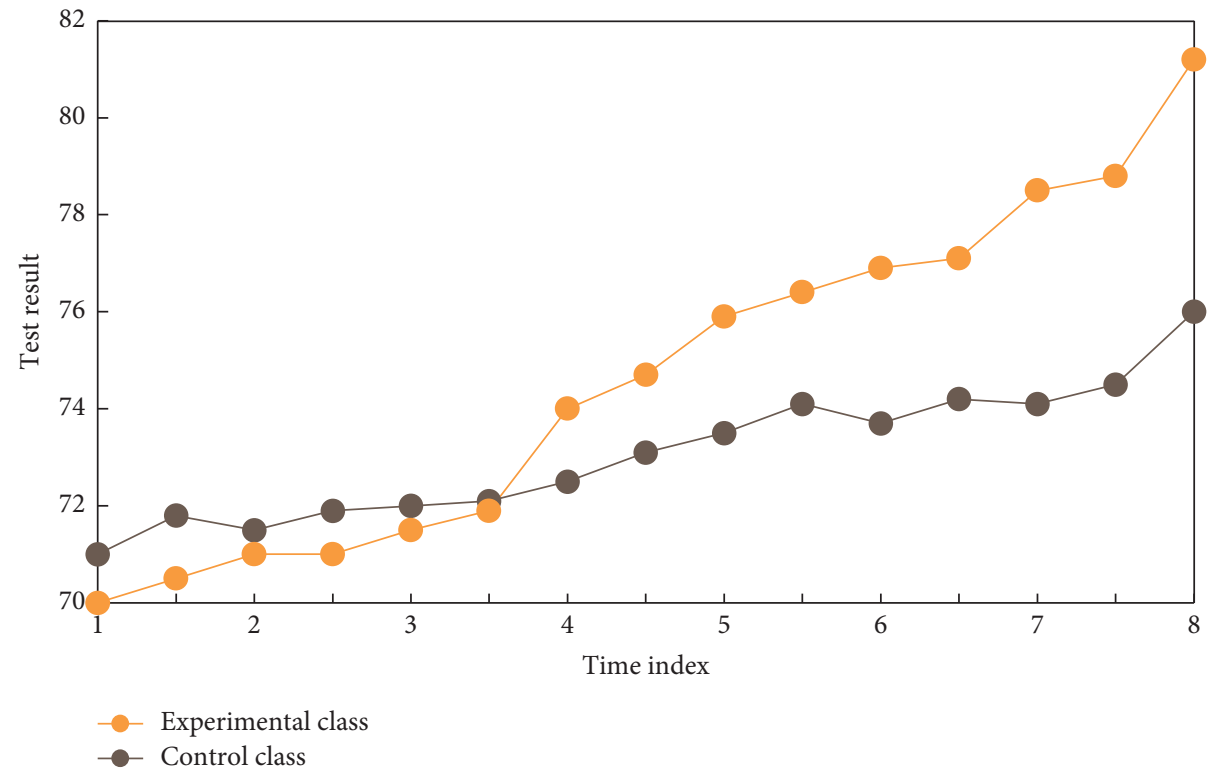

Figure 7: Comparison of effective words in composition.

Scientific and effective classroom teaching evaluation can guide teachers to update their ideas, internalize new ideas into classroom teaching behaviors, and inspire teachers to have a strong research desire in their hearts. Teachers cannot allow students to chat or discuss freely. Instead, they should prepare corpora in advance and give students timely help. Listening class leaves the traditional language lab and is placed in the multimedia classroom. Teachers can make full use of words, pictures, sounds, images, and so on to express teaching contents and carry out teaching activities. Comparison of class scores before and after the experiment is shown in Figure 8.
College English effective classroom environment construction and evaluation scale reflect the three dimensions of teaching process and the path model with good fit with learning effect can be established. It is consistent with the theoretical model's basic explanation that the teaching process influences the learning effect. Simultaneously, it clarifies the path by which the three dimensions of an effective CET classroom environment influence the learning effect. Classroom evaluation should be guided by a developmental teaching perspective, with the goal of promoting teachers' ongoing professional development and teaching level improvement. Teachers' correct guidance will play a 


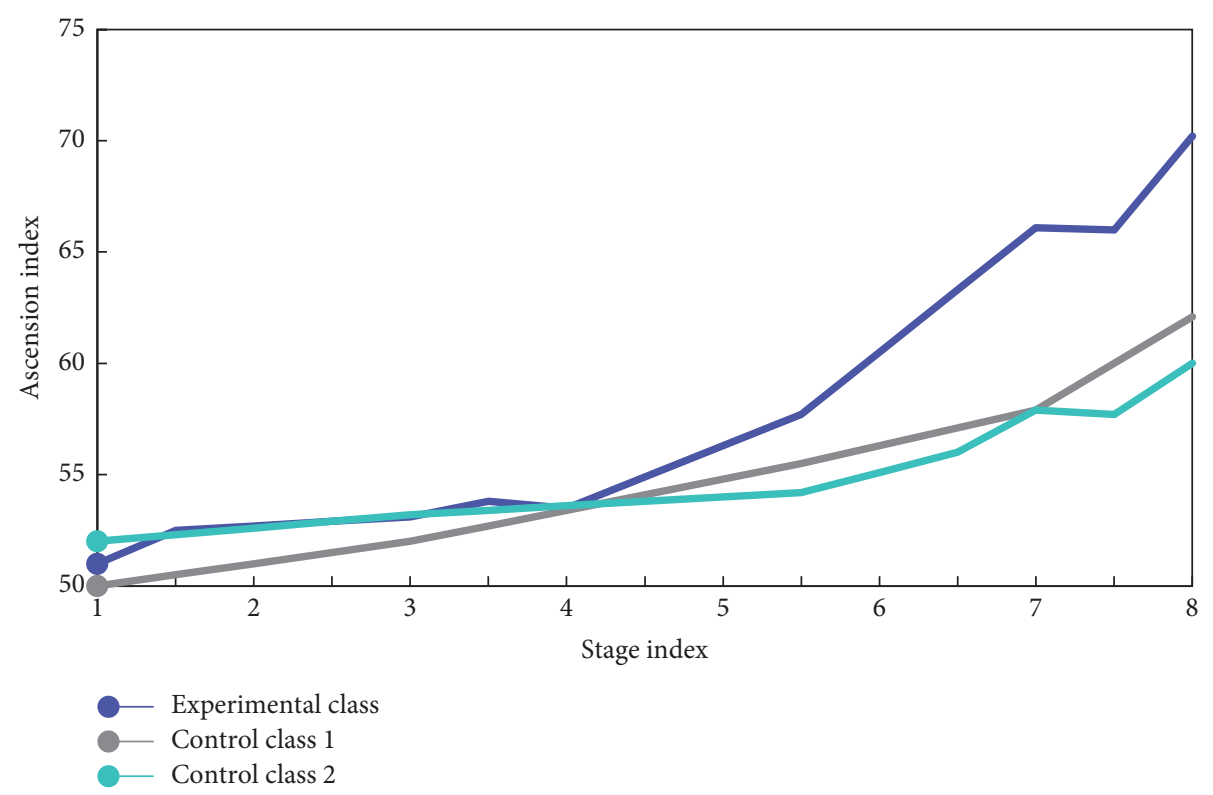

Figure 8: Comparison of class performance.

positive role in learners' correct use of online English learning resources, according to teaching practice. Learners' awareness of participation will be enhanced in a multimedia network environment.

\section{Conclusions}

As a teaching aid, multimedia can embellish the teaching environment through various forms for teachers, thus enriching classroom activities, attracting students' attention, and improving their autonomous learning ability. Multimedia is beneficial to stimulate learners' enthusiasm. In the English classroom under the multimedia network environment, learners are stimulated by sounds, images, and words, and their language knowledge and cultural knowledge in longterm memory are stimulated and transformed into short-term memory, thus stimulating learners' enthusiasm. Because of the emotional mobilization, learners activate their thinking and stimulate their awareness of cooperation with others. This kind of cooperation includes both cooperation with classmates and teachers. The multimedia network environment has created a good language learning situation for learners, and the cooperative relationship between learners and teachers has been further consolidated and strengthened. Education reform should explore the role of network teaching, which not only helps enhance the communication between teachers and students but also helps improve students' autonomous learning ability.

\section{Data Availability}

The data used to support the findings of this study are included within the article.

\section{Conflicts of Interest}

The author declares no conflicts of interest.

\section{References}

[1] L. Wang, "A preliminary study of multimedia-assisted English reading teaching in senior high schools under the network environment," English for Middle School Students, vol. 797, no. 14 , p. $128,2020$.

[2] D. Marcos-Jorquera, M. L. Pertegal-Felices, A. JimenoMorenilla, and R. Gilar-Corbí, "An interdisciplinary practical for multimedia engineering students," IEEE Transactions on Education, vol. 60, no. 1, pp. 8-15, 2016.

[3] J. A. Melian-Melian and J. Martin-Gutierrez, "Approaches to learning of engineering graphics through learning objects multimedia," International Journal of Engineering Education, vol. 35, no. 3, pp. 889-900, 2019.

[4] D. A. Patterson, "Education for chemical engineers 6 (2011) e10-e30 impact of a multimedia laboratory manual: investigating the influence of student learning styles on laboratory preparation and performance over one semester," Education for Chemical Engineers, vol. 6, no. 1, pp. 10-30, 2018.

[5] C. E. Baukal Jr. and L. J. Ausburn, "Multimedia category preferences of working engineers," European Journal of Engineering Education, vol. 41, no. 5, pp. 482-503, 2016.

[6] C. Deng, "Problems and countermeasures of using multimedia to assist English teaching in distance education," Journal of Hubei Correspondence University, vol. 30, no. 15, p. 3, 2017.

[7] H. Hartman and P. Johnson, "The effectiveness of multimedia for teaching drug mechanisms of action to undergraduate health students," Computers \& Education, vol. 125, no. 10, pp. 202-211, 2018.

[8] G. Powell-Cope, K. M. Pippins, and H. M. Young, "Teaching family caregivers to assist safely with mobility," AJN, American Journal of Nursing, vol. 117, no. 12, pp. 49-53, 2017.

[9] J. S. Halonen, S. A. Nolan, S. Frantz et al., "The Challenge of assessing character: measuring APA goal 3 student learning outcomes," Teaching of Psychology, vol. 47, no. 4, pp. 285-295, 2020.

[10] A. C. Phillips, L. K. Lewis, M. P. Mcevoy et al., "Development and validation of the guideline for reporting evidence-based practice 
educational interventions and teaching (GREET)," BMC Medical Education, vol. 16, no. 1, p. 237, 2016.

[11] C. Redmond, C. Davies, D. Cornally, M. Fegan, and M. O'Toole, "Teaching and learning in the biosciences: the development of an educational programme to assist student nurses in their assessment and management of patients with wounds," Journal of Clinical Nursing, vol. 25, no. 17-18, pp. 2706-2712, 2016.

[12] M. J. Kennedy, S. E. Hirsch, S. E. Dillon, L. Rabideaux, K. D. Alves, and M. K. Driver, "Using Content acquisition podcasts to increase student knowledge and to reduce perceived cognitive load," Teaching of Psychology, vol. 43, no. 2, pp. 153-158, 2016.

[13] B. J. Mackay, J. Anderson, and T. Harding, "Mobile technology in clinical teaching," Nurse Education in Practice, vol. 22, pp. 1-6, 2017.

[14] J. Fernandez-Rio and J. I. Menendez-Santurio, "Teachers and students' perceptions of a hybrid sport education and teaching for personal and social responsibility learning unit," Journal of Teaching in Physical Education, vol. 36, no. 2, pp. 185-196, 2017.

[15] T. Nkambule, T. G. Mukeredzi, and T. G. Mukeredzi, "Preservice teachers' professional learning experiences during rural teaching practice in Acornhoek, Mpumalanga Province," South African Journal of Education, vol. 37, no. 3, pp. 1-9, 2017.

[16] L. Cardenas Cantos, J. Lopez Izquierdo, and E. Cardenas Cantos, "Interactive multimedia application for teaching and learning in analytical geometry," IEEE Latin America Transactions, vol. 14, no. 7, pp. 3461-3466, 2016.

[17] J. Wang and L. Wu, "Research on multimedia-assisted CET," Journal of Jilin Radio and Television University, vol. 1, no. 3, p. 2, 2017.

[18] J. Shen, M. Wang, and T. S. Chua, "Accurate online video tagging via probabilistic hybrid modeling," Multimedia Systems, vol. 22, no. 1, pp. 99-113, 2016.

[19] H. Tu and F. Wang, "The role of multimedia-assisted teaching in English teaching," Collection of Contemporary Teaching Research, vol. 5, no. 10, p. 1, 2016.

[20] L. Zhu, "Analysis of the effectiveness of multi-media technique in assisting junior high school English grammar teaching," Contemporary Educational Practice and Teaching Research: Electronic Edition, vol. 3, no. 10, p. 1, 2016.

[21] X. Yuan, "Research on the positive and negative factors of multimedia-assisted English teaching for students," Chinese Journal of Multimedia and Network Teaching (Mid-Term), vol. 6, no. 02, pp. 65-66, 2020.

[22] J. Jiang, "On the effectiveness of group activities in English teaching under the aid of multimedia," Education Information Forum, vol. 4, no. 3, p. 2, 2020.

[23] H. L. Schnackenberg, E. S. Vega, and D. A. Simard, "Paradigm shift," Journal of Cases on Information Technology, vol. 16, no. 2, pp. 1-12, 2014.

[24] A. Kelliher, "Technology and the arts: educational encounters of the third kind," IEEE Multimedia, vol. 23, no. 3, pp. 8-11, 2016.

[25] B. Li, X. Liu, K. Dinesh, Z. Duan, and G. Sharma, "Creating a multi-track classical musical performance dataset for multimodal music analysis: challenges, insights, and applications," IEEE Transactions on Multimedia, vol. 8, no. 2, pp. 522-535, 2016.

[26] A. N. N. S. I. Septiani and T. Rejekiningsih, "Development of interactive multimedia learning courseware to strengthen students' character," European Journal of Educational Research, vol. 9, no. 3, pp. 1267-1280, 2020. 